\title{
Sustainable Development: Through Micro Hydro-Power Projects in Uttarakhand
}

\author{
Dr. Kartikey Hari Gupta ${ }^{1}$
}

${ }^{1}$ High Court of Uttarakhand and Supreme Court of India, India

Correspondence: Kartikey Hari Gupta, An Advocate practicing in the High Court of Uttarakhand and Supreme Court of India, he holds Ph.D. in Law on Sustainable Development Law, India. E-mail: kartikeyhari@gmail.com

Received: December 27, 2015 Accepted: January 22, 2016 Online Published: March 30, 2016

doi:10.5539/jsd.v9n2p162

URL: http://dx.doi.org/10.5539/jsd.v9n2p162

Development is as perennial as planet Earth itself. It was happening even when people did not start measuring it in time and space. Since the time development of human civilizations started being measured and then perhaps we realized that our resources are not unlimited. And we began conscious about the source of our resources i.e. nature.

Development having trans-anthropocentric approach is sustainable development. Generally understood idea of environment and ecology protection, added with the principles of economic and social development, transforms into the concept of sustainable development. Below figure shows the idea of sustainable development and its constituent components.

\section{Sustainable Development Components}

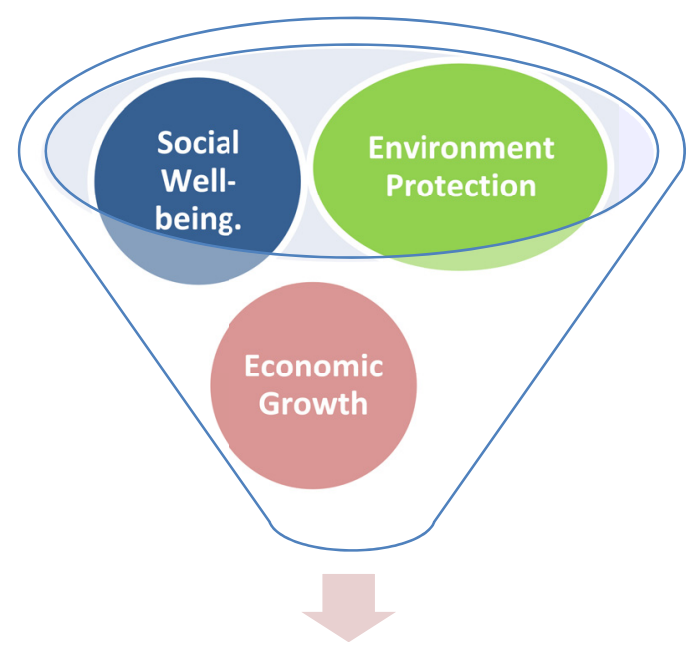

Sustainable Development

Figure 1.

Literally sustainable development has been defined by the Black's Law Dictionary as: “ The use of natural resources in a manner that can be maintained and supported over time, taking into account the needs of future generations." 1 Oxford English Dictionary defines sustainable development as: "Conserving an ecological balance by avoiding depletion of natural resources."

Sustainable development is possible when the equality and equity based distribution of resources is ensured, when social well-being is prioritized in the collective efforts of a society and when ecology and environment protection

${ }^{1}$ Black's Law Dictionary, Tenth Edition, Thomson Reuters, 2014, p. 1676.
${ }^{2}$ Oxford Dictionary of English,Third Edition,Oxford University Press, 2010, p. 1793. 
is made a preliminary requirement of any basic ingredient of all growth models. Sustainable development is about ensuring a fine balance amongst social up-liftment, economic growth and environment protection. Contemporary jurisprudence has very recently recognized the role of social and economic factors in the overall developmental process. Hitherto sustainable development jurisprudence has always been pre-dominated with the ideas of environment and ecology protection. Chanakya in its Arthshastra has provided various duties of the king and subjects towards the nature. ${ }^{3}$ King Ashoka's ( $5^{\text {th }}$ Pillar Edict) has instructed its people to respect the nature and provided various measures to live in harmony with the animals. ${ }^{4}$ It was actually with the advent of Industrial Revolution in Britain the trouble started. Resource consumption was at its height and they looked around the world with the similar intentions, which was one of the major reasons for colonial imperialism. Then we realized that the time has come for some serious thinking. After the two Wars (I and II World Wars), of great greed and insanity finally the institutionalization of the concept of sustainable development started to begin.

Environment may connote different meanings in different contexts. In its common understanding, environment consists of the surroundings- air, water, soil etc. and to be more general our habitat. Broadly we can divide environment into two specific concepts, one is natural environment and the other is built environment. Natural environment consists of all living and non-living things that occur naturally on Earth and the built environment include the buildings, roads, parks, gardens, powerhouses, dams and other human made things. As defined in Section 2 (a) of the Environment Protection Act, 1986, the term "environment" has been means to "include water, air and land and the inter-relationships which exist among and in between water, air and land, human beings and other living creatures, plants, micro-organisms and property". 5

The concept of sustainable development is all about harmonious coexistence of natural as well as manmade environment. Development must be such which can be sustained by the future generations. We cannot grow haphazardly, we have to develop equitably. The elements of intergenerational equity and a trans-anthropocentric approach must be given real considerations while chalking out any developmental activity. Humanity's demand for resources of the planet has more than doubled over the past century as a result of population growth and increasing per capita consumption. The later half of the twentieth Century witnessed a phenomenal increase in population and industry led urbanization of people which has been supplemented by increase in food production, energy usage and economic activities.

As the world has become more industrialized, there have been increasing pressures on environment and earth resources resulting into harmful emissions and waste, which have had global, regional or local impacts. These include, at the local level, urban air pollution, contamination of soils and rivers and land degradation; regionally, acid rain and water and coastal zone contamination; and globally, climate change, ozone layer depletion, loss of biodiversity, trans-boundary movement of hazardous waste and increased land-based marine pollution. Challenges for Sustainable Environment are elucidated in Table 1 below.

Table 1.

\section{Challenges for Sustainable Environment}

$$
\text { Regional }
$$

\section{Global}

Urban Air Pollution.

Climate Change.

Noise Pollution.

Threat for Polar Regions

Rapid Soil Erosion

Ozone Layer Depletion

Contamination of Rivers,

Loss of Bio-Diversity

Ponds and other water bodies.

Population Explosion

Poverty

Trans-boundary movement of hazardous waste, Marine pollution

Terrorism

The issues confronting the development process today are to achieve desired development for economic or social reasons on one hand and safeguarding the environment and maintaining good quality living conditions on the

\footnotetext{
${ }^{3}$ Kautilya, Arthashastra, Translated by R. Shamasastry, Government Press, Bangalore, 1915, p. 515-520.

4 Ven. S. Dhammika, The Edicts of King Asoka, Bhuddist Publication Society, Kandy (Sri Lanka), 1993, p. 18.

${ }^{5}$ Section 2 (a) The Environment (Protection) Act, 1986.
} 
other. The haphazard and uncontrolled developmental activities are the primary reason for over use of natural resources, congestion, incompatible land-use and poor living conditions. The problems of habitat pollution are becoming complex and are creating a high risk environment.

Sustainable development is the only answer present generation can give to the future generations when asked about the use of Earth resources. As far as the legal arena is concerned International law on sustainable development is as usual not more than a soft law in the form of various treaties and conventions. Sustainability principles are yet to permeate into the domestic legislations of almost all countries of the world. In India sustainability facets of legislations are yet to be legislated. Being one of the largest populated country on the planet balancing the growing demands of its population with the sustainable development principles shall be another challenge before the Indian law makers.

India has enacted some landmark legislations in recent past ensuring the social wellbeing and economic security like The Mahatma Gandhi National Rural Employment Guarantee Act 2005, National Food Security Act 2013, Right of Children to Free and Compulsory Education (RTE) Act 2009 for its billion plus population (most of them below poverty line by the global standards). Such kind of beneficial legislations are necessary for balancing the economic growth with the social and economic wellbeing of it weaker sections to ensure a sustainable development of society.

Development has been defined differently every time depending on the time and space of the study. A very specific purpose of this research work is to find connotations of development and the contours of sustainable development presently in the State of Uttarakhand. Predicament to be answered through this paper is the Right to Development versus Right to Environment. In a state like Uttarakhand, where even basic medical and educational facilities are a distant dream, has sustainable development some different context from rest of the world. Do this remote state and its remoter people entitled to some head-start in this so called globalized and growth oriented world? Himalayan State has the credit of giving birth to the Modern Indian Environmental Movement. On the 27th of March 1973 - exactly 40 years ago - a group of peasants in a remote Himalayan village stopped a group of loggers from felling a patch of trees. Thus was born the Chipko movement, and through it the modern Indian environmental movement itself. ${ }^{6}$ In the 1980s and 1990s, the finest minds in the environmental movement sought to marry science with sustainability. They sought to design, and implement, forest, energy, water and transport policies that would augment economic productivity and human welfare without causing environmental stress. They acted in the knowledge that, unlike the West, India did not have colonies whose resources it could draw upon in its own industrial revolution. ${ }^{7}$

The new State of Uttaranchal now renamed as Uttarakhand was formed under Article 3 of the Constitution of India by an Act of Parliament known as Uttar Pradesh Reorganization Act, 2000 (from hereinafter referred to as the 'Reorganization Act'). The new State of Uttarakhand came into existence on the 'appointed day' which is 9th November, 2000. Reorganization Act, 2000 does not contain any preamble for any specific purpose of the creation of the new State; however the new State was created for the specific reason of the development of the hilly regions hitherto considered backward and less developed of the erstwhile State of Uttar Pradesh.

Since the creation of the new State many development initiatives have been taken by the people of the state. Uttarakhand is a very rich State in terms natural resources. Hydro power has been one of the key areas in which considerable development has been done by the state. The most successful hydro power project of the State is Tehri Hydro Power Project. Preliminary investigation of the Tehri Dam was done in 1961 with a 600 MW capacity power plant for which the technical and financial assistance was to be provided by the then USSR. With the change of the political circumstances of the supporting nation, India itself had to take over the project completely and the project was placed under the direction of the Irrigation Department of the then state of Uttar Pradesh. In 1988, the Tehri Hydro Development Corporation was formed to manage the dam with the $75 \%$ of the funding by the Central government and $25 \%$ by the State government. Tehri Dam having height of 261 meter and claimed $8^{\text {th }}$ tallest hydro power dam in the world.

Tehri Dam may be taken as a good example of sustainable development efforts, balancing ecology and development in the State. Although many environmentalist have time and again challenged the sustainability of the project. Issues related to the catchment area development, command area development and religious sensibility of the river Bhagirathi were raised during its completion and implementation. Construction and the

\footnotetext{
${ }^{6}$ See Ramchandra Guha, The Past and Present of Indian Environmentalism, The Hindu, March 27, 2013, article available at www.thehindu.com/opinion.

${ }^{7}$ Ibid
} 
final commissioning of the Tehri Dam addressing also all the sustainability issues have been a major success story of the state and its people.

Uttarakhand is a young State with rapid economic growth and it has made constant efforts to incorporate sustainable development jurisprudence in its policy initiatives. Sustainable development tenets are all the more important for the State of Uttarakhand as most of the people here are dependent on their natural habitat which is evident from the fact that over three-fourths of the total population is dependent on agriculture for its livelihood. The State has over 15 important rivers and over a dozen glaciers in its land thus also a valuable freshwater reserve. About 200 large and medium sized hydro-power projects are in operational or in various stages of development therefore hydroelectricity gets credit to be a prime source of capital for the local economy. Maintaining the 'high precautionary approach' towards the sustainability of the environment and ecology comprehensive EIAs (environment impact assessments) are a necessary part of the hydro-power projects of the State. Speaking at the Uttarakhand Sustainable Development Summit (USDS) 2008 organized by the Government of Uttarakhand and The Energy and Resources Institute (TERI) in Dehradun the then Chief Minister Major General B.C.Khanduri stressed as " the State needs a people friendly and rural oriented model of development that does not disrupt the life of masses an the livelihoods of the rural population, but helps them grow in every aspect of life, be it economic development or ecological development or management of natural resources."

Incorporating natural resource friendly policies and practices is important for the state as it is one of the most vulnerable to the impact of climate change despite its rich natural resource heritage. Sustainability audit is the need of the hour for all the new and old hydro-power projects of the State. As a new State Uttarakhand has a chance to lay a planned blueprint of its growth. Because of a very rich natural environment this State need the policies which ensures sustainable development in the State.

Uttarakhand has an estimated hydro-power potential of approximately 20,000 MW against which only about 3,124 MW has been harnessed so far ${ }^{9}$. The position with regard to the sources of energy supply and consumption of energy based on use for the year 2008-09 was assessed by the Comptroller and Auditor General of India (CAG) while doing performance audit of the hydropower development through private sector participation in the State of Uttarakhand. Sources of energy were identified by the CAG as under:

Sources of Energy identified by CAG

Table 2.

\section{Sources of Energy in State of Uttarakhand}

(In Million Units (MUs)

\begin{tabular}{cccc}
\hline 1. & Own Sources & $4419.08 \mathrm{MUs}$ & $52 \%$ \\
2. & Central Pool & $3379.57 \mathrm{MUs}$ & $39 \%$ \\
3. & Other Sources & $770.22 \mathrm{MUs}$ & $9 \%$ \\
\hline
\end{tabular}

Source: $\quad$ See Performance Audit Report available online at:
http://saiindia.gov.in/english/home/Our_Products/Audit_Report/Government_Wise/state_audit/recent_reports/Ut tarakhand/2009/performance_Audit/performance_Audit_Uttarakhand_2009/pa_chap1.pdf.

It is very clear from the above data that State of Uttarakhand is way behind in its ambition of becoming an energy surplus state. State is able to meet only 52 per cent of its power needs from its own resources. Looking at the grim state of affairs of the power production and distribution of energy in the state, the state governments time to time emphasized on the construction of hydroelectricity projects in the State. Apart from the production pattern consumption pattern has also been identified by the CAG as under.

\section{Consumption of Energy identified by the CAG}

\footnotetext{
${ }^{8}$. See http://news.oneindia.in/2008/06/19/khanduri-sustainable-development-natural-resource-management-uttarakhand-1213878600.html.

9 See Performance Audit Report available online at :

http://saiindia.gov.in/english/home/Our_Products/Audit_Report/Government_Wise/state_audit/recent_reports/Uttarakhand/2009/performanc e_Audit/performance_Audit_Uttarakhand_2009/pa_chap1.pdf.
} 
Table 3.

\begin{tabular}{ccccc}
\hline \multicolumn{5}{c}{$\begin{array}{c}\text { Consumption of Energy in State of Uttrakhand } \\
\text { based on 2008-2009 }\end{array}$ data (In Million Units (MUs) } \\
\hline 1. & Domestic & 1222.22 & MUs & $22 \%$ \\
2. & Commercial & 763.92 & MUs & $14 \%$ \\
3. & Irrigation & 266.01 & MUs & $5 \%$ \\
4. & Industrial & 2980.84 & MUs & $54 \%$ \\
5. & Others & 260.76 & MUs & $5 \%$ \\
\hline
\end{tabular}

Source: See Performance Audit Report prepared by the Comptroller and Auditor General of India. Report available online at:

http://saiindia.gov.in/english/home/Our_Products/Audit_Report/Government_Wise/state_audit/recent_reports/Ut tarakhand/2009/performance_Audit/performance_Audit_Uttarakhand_2009/pa_chap1.pdf.

Hydro power projects are in the nature of the high dams with large generation capacity and small run of the river projects. Looking into the sustainability and community friendly aspects the State of Uttarakhand has encouraged the small run of the river projects. State of Uttarakhand framed a policy for the small hydro-power projects upto the capacity of $25 \mathrm{MW}$. Defining the scope for the small hydro power development in the state it said, "Uttaranchal has a hydropower potential of the order of $20236 \mathrm{MW}$ against which only about 1407 MW has been harnessed so far. The Government of Uttaranchal has decided to encourage generation of power through small hydropower sources of energy, and has framed a policy so that the development of this sector serves as an engine to achieve the objective of promoting the all-round development of the region. ${ }^{10}$ In the Year 2001 Uttarakhand State created a specialized state operated company called Uttarakhand Jal Vidyut Nigam (UJVNL). UJVNL is a wholly owned Corporation of the Government of Uttarakhand set up for managing hydro power generation at existing power stations and development, promotions of new hydro projects with the purpose of harnessing, the known, and yet to be known, hydro power resources of the State. ${ }^{11}$

Due to hill terrain in the State it was found in Uttarakhand by the power infrastructure laying agencies to link all the areas to the grid. A large part of the State land being under the forest and reserve parks like Corbett National Park and Nandadevi Wildlife Reserve increased the problem of linking electricity distribution lines to the transmission lines or to the grid. To tackle this problem policy makers found micro power production as a viable solution in the remote and rural areas and for that Uttarakhand Renewable Energy Development Agency (UREDA), was created for decentralized production and supply of power in the remote villages which are not connected to the grid either due to their remoteness or because of the scattered nature of the villages throughout the mountainous areas of the State. Micro hydro projects are in the nature of stand-alone projects and built for the definite need of a local area.

Himalayan State tackled this problem in a very unique way. It started Decentralized Distributed Generation (DDG) through Micro and Mini Hydro Projects which are suitable and best way to provide electricity facility to the forest fringe and scattered villages. In the absence of National and State grid lines to these remote villages a large number of MHPs are being commissioned by the State for stand-alone generation and supply of electricity. UREDA which is a nodal agency for this purpose has commissioned large number of MHPs in the remote areas of state where the National or State grid cannot be extended. Total 41 MHPs of total capacity 3.960 MW has been installed in the remote villages of Uttarakhand till date and another 18 MHPs of total capacity 1.965 MW are under implementation.

Below mentioned tables amply describes the potential as well as the need of the micro hydro power projects in the State of Uttarakhand. Because of its geographical conditions this State need more and more micro power generation. Remote areas of hills and scattered population settlements mandated the policy makers in the state to generate electricity more and more through micro hydro projects and also ensure decentralized distribution of power. Instead of the the grid supply which is very well effective in the large cities and in places having concentrated population decentralized generation and distribution is more suitable to the needs of the Himalayan State.

10 See http://www.ireda.gov.in.

${ }^{11}$ See http://www.uttarakhandjalvidyut.com. 
MHPs Commissioned during the Year 2010-11 and MHPs under construction in the state are stated in Table 4 and 5 respectively.

Micro Hydro-Projects Commissioned in the State

Table 4.

MHPs Commissioned during the Year 2010-11

\begin{tabular}{|c|c|c|c|c|c|}
\hline \multirow[t]{2}{*}{ Sl. } & \multirow[t]{2}{*}{ District } & \multirow[t]{2}{*}{ Project } & \multirow[t]{2}{*}{ Capacity (KW) } & \multicolumn{2}{|c|}{ Electrified } \\
\hline & & & & Nos. of Villages & Nos. of Hamlets \\
\hline 1 & Tehri & Jakhana & 100 & 3 & 4 \\
\hline 2 & Chamoli & Bank & 100 & 5 & 3 \\
\hline 3 & Chamoli & Gamsali-Bampa & 50 & 2 & - \\
\hline 4 & Bageshwar & Lamabagar & 200 & 4 & 4 \\
\hline 5 & Bageshwar & Borbalada & 25 & 1 & 2 \\
\hline 6 & Uttarkaski & Taluka & 25 & - & 1 \\
\hline \multicolumn{3}{|c|}{ Total } & 500 & 15 & 14 \\
\hline
\end{tabular}

Source: Department of Renewable Energy - Govt. Of Uttarakhand, Last updated on 18-03-2013 data available online at: http://ureda.uk.gov.in/pages/display/131-micro-hydro-projects

After looking at the success of the abovementioned micro-hydro projects the State government encouraged more generation of electricity through this model and below mentioned table shows such encouragement to the micro-hydro projects in the State. Villages and hamlets of the villages shall be the direct beneficiary of this idea.

Micro Hydro-Projects under construction in the State

Table 5.

\begin{tabular}{|c|c|c|c|c|c|}
\hline \multirow[t]{2}{*}{ SI. } & \multirow[t]{2}{*}{ District } & \multirow[t]{2}{*}{ Project } & \multirow{2}{*}{$\begin{array}{c}\text { Capacity } \\
\text { (KW) }\end{array}$} & \multicolumn{2}{|c|}{ To be Electrified } \\
\hline & & & & Nos. of Villages & Nos. of Hamlets \\
\hline 1 & Almora & Tarula & 100 & 5 & 3 \\
\hline 2 & Bageshwar & Lamchula & 50 & 2 & 2 \\
\hline 3 & Bageshwar & Gogina-II & 50 & 3 & - \\
\hline 4 & Bageshwar & Wachham & 500 & 2 & 8 \\
\hline 5 & Pauri & Gaudi Chida & 250 & \multicolumn{2}{|c|}{ Grid Feeding } \\
\hline 6 & Chamoli & Hafla & 200 & \multicolumn{2}{|c|}{ Grid Feeding } \\
\hline 7 & Chamoli & Nigolgad & 100 & \multicolumn{2}{|c|}{ Grid Feeding } \\
\hline 8 & Uttarkashi & Khapugad & 40 & 1 & - \\
\hline 9 & Tehri & Pinswad & 50 & 2 & - \\
\hline 10 & Tehri & Kotijhala & 200 & 4 & 1 \\
\hline 11 & Uttarkashi & Chiludgad & 100 & 4 & - \\
\hline 12 & Pithoragarh & Rotan & 50 & 3 & 2 \\
\hline 13 & Pithoragarh & Duktu & 25 & 2 & - \\
\hline 14 & Pithoragarh & Nagling & 50 & 3 & - \\
\hline 15 & Pithoragarh & Sela & 50 & 1 & - \\
\hline 16 & Pithoragarh & Kutty & 50 & 1 & - \\
\hline 17 & Pithoragarh & Napalchu & 50 & 2 & - \\
\hline
\end{tabular}




$\begin{array}{llcccc}18 & \text { Pithoragarh } & \text { Bundi } & 50 & 1 & - \\ \mathbf{1 9} & \text { Pithoragarh } & \text { Rongkong } & 50 & 1 & - \\ \mathbf{2 0} & \text { Rudraprayag } & \text { Kedarnath II } & 200 & 1 & \text { Kedarnath Dham } \\ & \text { Total } & & 2215 & 38 & 16\end{array}$

Source: Department of Renewable Energy - Govt. Of Uttarakhand, Last updated on 18-03-2013 data available at: http://ureda.uk.gov.in/pages/display/131-micro-hydro-projects

Above data amply confirms the success of the Micro Hydro Projects in the State. Apart from the isolated villages another very important achievement reached through these micro hydro projects is the supply of electricity to the shrines. Badrinath Shrine, Kedarnath Shrine, Yamunotri Shrine and Gangotri Shrine,Hemkund Shrine Jageshwar Temples etc. are the religious places of national importance, due to these Uttarakhand has a peculiar place in the religious and mythological map of the country. Four utmost important religious shrines of Hindus are in the State. UREDA has successfully implemented the micro hydro projects in the four shrines resultantly these shrines now no more depend on the power supply from the grid. All the power to these shrines comes from the micro hydro projects installed locally.

Decentralized generation and distribution to the Shrines

Table 6.

\begin{tabular}{lllll}
\hline \multicolumn{4}{c}{ Self-Sustaining Green Power Supply through MHP Model } \\
\hline Sl. & Shrine & Type & Capacity & Agency \\
1. & Kedarnath Shrine & MHP & $100 \mathrm{KW}$ & UREDA \\
2. & Yamunotri Shrine & MHP & $2 \times 100 \mathrm{KW}$ & UREDA \\
3. & Gangotri Shrine & MHP & $3 \times 50 \mathrm{KW}$ & UREDA \\
4. & Hemkund Sahib & MHP & $2 \times 50 \mathrm{KW}$ & UREDA \\
\hline
\end{tabular}

Source: Data based on calculations of Uttarakhand Renewable Energy Development Agency under Department of Renewable Energy, Government of Uttarakhand, available at: http://ureda.uk.gov.in/pages/display/55-shrine-electrification

The above mentioned model indicates that the concept of micro hydro projects for remote area electrification in the State of Uttarakhand is completely sustainable as well as having minimal or no impact on the surrounding natural habitat. It is a self-sustaining Green Power Supply model possible only through the concept of Micro Hydro Projects.

\section{Copyrights}

Copyright for this article is retained by the author(s), with first publication rights granted to the journal.

This is an open-access article distributed under the terms and conditions of the Creative Commons Attribution license (http://creativecommons.org/licenses/by/3.0/). 